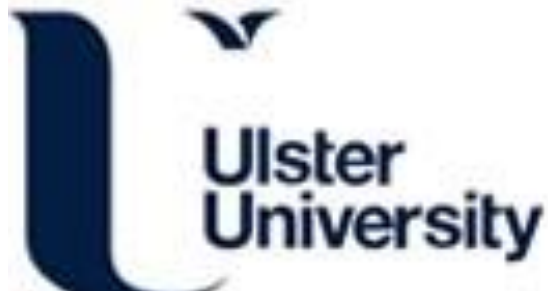

SCOUR-INDUCED FAILURE OF MASONRY ARCH BRIDGES: CAUSES AND COUNTERMEASURES

Solan, B., NOWROOZPOUR, ALIREZA., Clopper, P., Watters, C., \& Ettema, R. (2019). SCOUR-INDUCED FAILURE OF MASONRY ARCH BRIDGES: CAUSES AND COUNTERMEASURES. In E-proceedings of the 38th IAHR World Congress

Link to publication record in Ulster University Research Portal

Published in:

E-proceedings of the 38th IAHR World Congress

Publication Status:

Published (in print/issue): 06/09/2019

\section{Document Version}

Author Accepted version

\section{General rights}

Copyright for the publications made accessible via Ulster University's Research Portal is retained by the author(s) and / or other copyright owners and it is a condition of accessing these publications that users recognise and abide by the legal requirements associated with these rights.

\section{Take down policy}

The Research Portal is Ulster University's institutional repository that provides access to Ulster's research outputs. Every effort has been made to ensure that content in the Research Portal does not infringe any person's rights, or applicable UK laws. If you discover content in the Research Portal that you believe breaches copyright or violates any law, please contact pure-support@ulster.ac.uk. 


\title{
SCOUR-INDUCED FAILURE OF MASONRY ARCH BRIDGES: CAUSES AND COUNTERMEASURES
}

\author{
BRIAN SOLAN(1), ALIREZA NOWROOZPOUR(2), PAUL CLOPPER(3), CLAIRE WATTERS(4), and ROBERT \\ ETTEMA ${ }^{(5)}$

\begin{abstract}
${ }^{1}$ Lecturer, School of the Built Environment, Ulster University, Newtownabbey, Co Antrim, U.K. BT37 0QB, b.solan@ulster.ac.uk ${ }^{2} \mathrm{PhD}$ student, Dept. of Civil and Environ. Eng., Colorado State University, Fort Collins, Colorado, USA; anowr@rams.colostate.edu ${ }^{3}$ Director, Applied Technology, Ayres Associates, Fort Collins, Colorado, USA; ClopperP@AyresAssociates.com ${ }^{4}$ Consultant, G. Neely Construction Ltd, Coleraine, Co. Londonderry, U.K., BT52 1AF, claire@buildgnc.com

${ }^{5}$ Professor, Dept. of Civil and Environ. Eng., Colorado State University, Fort Collins, Colorado, USA; rettema@engr.colostate.edu
\end{abstract}

\begin{abstract}
This paper discusses how flow conditions and consequent scour of channel bed induces the failure of shortspan, masonry arch bridges over small to medium sized rivers. Such bridges are common in Ireland, the U.K. and Europe. A factor frequently complicating failure is that such bridges typically are deemed historic structures and, therefore, are expensive to repair. A significant hydraulic-engineering factor is that, these bridges readily choke approaching flows, especially under large return period flooding conditions. The bridge flow area quickly decreases once flow stage reaches the crown of the arch barrel. Flume experiments, undertaken with choked flow condition, showed that three locations of masonry arch bridges are particularly prone to scour-induced erosion: piers (multi-span only), abutment corners and the channel bed immediately downstream of the bridge (in the case of a paved or protected bridge inverts). Scour can be reduced only modestly by streamlining abutments by means of wing walls, and cutwaters on piers, because of flow choking. The use of stone pitching to armour the riverbed around abutments and piers prevents scour at the front of, and beneath, the bridge. However, supercritical flow through the bridge opening may scour the channel bed immediately downstream of a bridge. Alternative scour-mitigation measures are suggested. The increased failure incidence of these bridges has raised concerns in the U.K. and Ireland that many masonry arch structures will be imperilled by the effects of greater flow rates associated with climate change and watershed urbanization. The situation is complicated by the age of the structures and the lack of accurate bridge records.
\end{abstract}

Keywords: alluvial river; arch bridges, flow contraction, asset failure

\section{INTRODUCTION}

Increased runoff flowrates have led to a growing number of scour-related failures of short-span, masonry bridges throughout the U.K. and Ireland (e.g., Van Leeuwen et al., 2014 Benn 2012, Ryan et al., 2015, 2016). A significant proportion of these bridges were built during the early eighteenth and nineteenth centuries. Given their age, these structures typically have shallow footing foundations of unknown depth and condition (O'Keefe et al., 2016). To complicate matters, old masonry-arch bridges often have protected status in the U.K. and Ireland owing to the historical and architectural contribution these structures make to the natural landscape. They cannot be simply demolished and replaced with new bridges but must be preserved for aesthetic reasons (e.g., McKibbins et al., 2006). Practically all old masonry arch bridges were built to accommodate much lesser flows than are occurring presently, especially during extreme storms. Current hydraulic design or remedial guides for bridges (e.g., Kirby et al., 2015, Arneson et al., 2012, Shan et al., 2012) have yet to suggest suitable scour assessment methods for this prevalent type and shape of bridge. Concerns regarding the stability and functionality of masonry arch bridges are not limited to the U.K. and Ireland, but also arise elsewhere (e.g., Citto et al., 2015). In certain respects, masonry arch bridges share a commonality with culverts (e.g., Novak et al., 2007), especially so-called bottomless culverts, (e.g., Kerenyi et al., 2003, 2007). The current design relationships for scour at bottomless culverts suggest that maximum scour occurs downstream of the bridge structure (e.g., Kerenyi et al., 2007). As this paper shows, this is not the case for single and multi-span arch structures. The typical flow conditions commonly observed during flood flows in the U.K. is that of choked flow (inlet control), with the inlet (the crown of the arch) submerged and the outlet usually not submerged (Hamill 1993, 1999). U.K. observations indicated that this flow combination would yield the essential insights regarding scour at existing masonry arch bridges. A further complication is that many old masonry bridges in Europe are supported by footing foundations of unknown depth and form (Wilmers 2012). This paper presents the findings from an investigative study regarding the hydraulics of flow and scour at masonry arch bridges and evaluates the extents to which traditional modifications (wing-wall-angling of abutments, cutwater shaping of pier noses, 
and armouring of the channel bed at a bridge) may mitigate scour. The findings build on the paper by Ryan et al. (2016), which details velocity profiles under flatbed testing conditions.

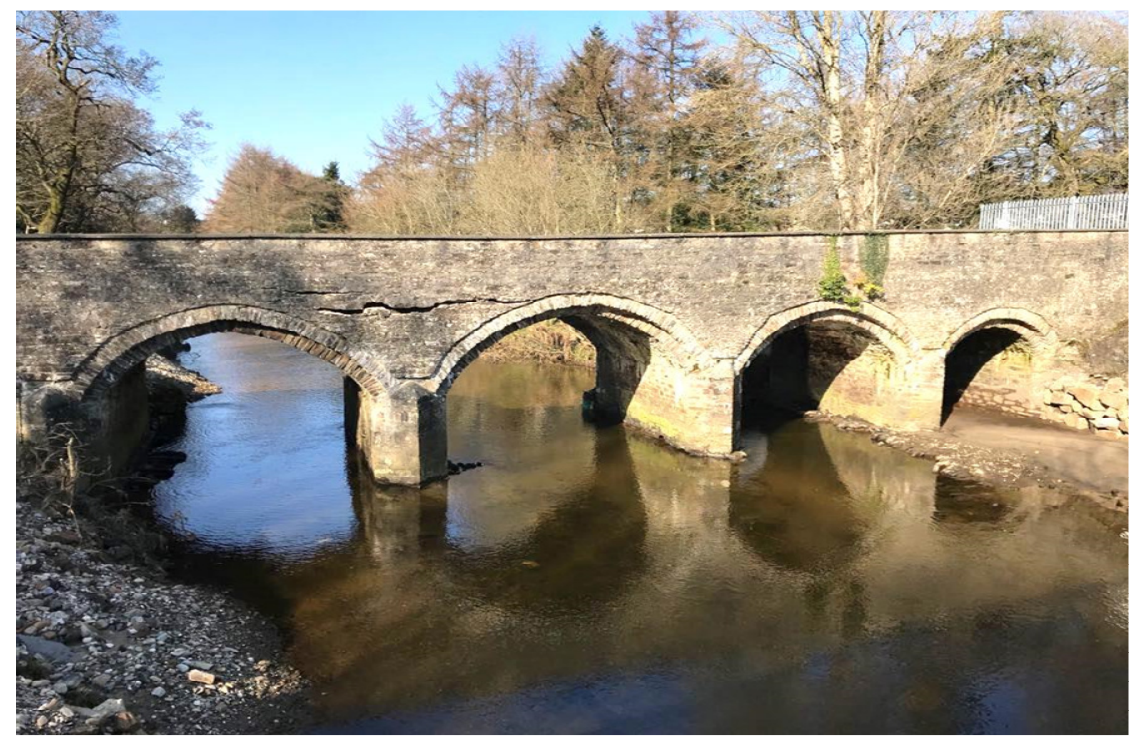

Figure 1. Scour at the front of the central pier led to scour-induced failure of failure of an arch bridge (Ballynameen Bridge) over the River Faughn near Cladys, Northern Ireland. (View looking from upstream of the bridge)

\section{ARCH BRIDGES ARE COMMON}

Short-span, masonry arch bridges are common throughout the U.K, Ireland, also Europe generally. Brencich et al., (2007), for example, suggest that about 200,000 masonry arch bridges support the European (including U.K.) railway network and that over 100,000 masonry arches are used throughout major European national road systems. Zampieri et al., (2017) describe the prevalence of old masonry arch bridges in Italy, for example. The U.K. Government $(2010,2011)$ notes that approximately half of the U.K.'s bridges (c. 58,000 bridges) are masonry bridges. McRobert (personal communication, Dfi 2015) of Northern Ireland's Department for Infrastructure-Roads (Dfl) notes that about $70 \%$ of Dfl's bridge stock comprises masonry arch bridges. In many cases, such structures are well over 100-years old, demonstrating durability, resilience, and aesthetic qualities Kindij et al., (2014). Salter (2013) in his talk to Engineers Ireland suggested there are upwards of 18,000 arch bridges in Ireland, many of which are upwards of 150-year-old. However, despite this impressive record, reports of scour-induced undermining of footing foundations are growing. The reports are not limited to the U.K.; Zampieri et al., (2017) elaborated an Italian case study where scour has led to a post-WWII reconstructed masonry arch bridge failing during flooding. A secondary source of concerns for arches is the complication of debris blockage during storm event. This remains a major aggravating aspect of flow through short-span bridges (e.g., Ebrahimi et al. 2016, Sassu et al. 2017) and exacerbates local scour (Lagasse et al. 20100. This review, and similar reviews, highlights that masonry arch bridges on shallow footings are vulnerable locations in the U.K's road and rail transportation network. Wilmers (2012) and the U.K. Government (2011) indicate that the preponderance of short-span arch bridge structures was constructed on shallow footing foundations, placed close to riverbed or ground level (typically less than about $3 \mathrm{~m}$ deep). A case in point is the Charlemont Bridge at the Moy near Dungannon, Northern Ireland (Kirby et al. 2015). Flooding had exposed the pile-supported timber grillage beneath the bridge footing, resulting in settlement and cracking of the upstream cutwater. Thus, even in cases where piles were used, masonry structures are still susceptible to scour related problems. A problematic issue for asset management of such historic structures is the lack of record drawings about foundation configuration and condition (Ryan et al., 2015, 2016). These issues are compounded by climate change and financial austerity, which adversely impacts the management of the current bridge stocks (Wiggins et al., 2018, Maddison 2012, Van Leeuwen et al., 2014).

\section{LARGER FLOWRATES}

Among anticipated consequences of global warming of the Earth's atmosphere is increased rainfall on Ireland and the U.K., and therefore larger runoff flowrates in rivers and streams. In recent years, the remnants of hurricanes spawned in the mid-Atlantic have reached further north than in the past and produced heavy rainfall. This concern is compounded by the growth of urbanization. Whereas once short-span masonry arch bridges were set in rural watersheds, increasingly these watersheds are becoming urbanized, with the consequence that masonry-arch bridges are experiencing larger flowrates. The situation is also exacerbated 
by the increasing global demand for food, which is also resulting in farmland drainage schemes that reduce catchment times of concentration.

In Northern Ireland during late August 2017, unprecedented flooding occurred. The storm event was related to the tail-end of Hurricane Gert passing the North Eastern seaboard of Ireland. The northwest of Northern Ireland (NI) was particularly impacted by this extreme weather system. This prompted a review by the Department for Infrastructure (Dfl) Northern Ireland on the flood alleviation and response measures needed during such happenings. The flooding event back analysis confirmed that $63 \%$ of the annual August rainfall fell within an 8-hour period and caused major disruption to the country's infrastructure (Dfl, 2018). The level of flooding was comparable if not greater than the largest 1:100-year event on records in numerous areas. In accordance with the European Floods Directive (EU, 2017), Dfl had generated Flood Hazard and Risk maps which predicted that this region of NI was very vulnerable to extreme flooding events. However, the Dfl 2018 report concluded that while the possibility of flooding was known, the response systems and protocols were inadequate in mitigating the devastation caused by the flood. Figure 1 dramatically demonstrates the impact of the recorded 1:280-year return period flow on Ballynameen Bridge outside Claudy Co Derry/Londonderry. In December 2015, Storm Desmond inundated the UK with 7 days of unprecedented rainfall, resulting in massive national flooding. Many areas were badly impacted by the storm, but the mountainous County of Cumbria, in North East England was particularly impacted (Mclntyre (2018)). The extensive rain breached flood defences, caused bridge failures and led to loss of human life (BBC 2015), a similar event also happened in 2009 in the same area, with comparable devastation.

\section{ARCH-BRIDGE HYDRAULICS}

The hydraulics of flow through arch bridges over waterways involves non-uniform and unsteady flow, both of which occur in a flow cross-section whose area relative to the approach-flow area decreases once the flow stage, matches the barrel of an arch (Owens et al., 1959). The flow is non-uniform, because the channel geometry changes and the bed roughness of the channel alters. The flow is unsteady because scour changes the opening geometry over time, until an equilibrium state is reached. Two further flow features need to be considered for arch bridges: the approach flow to the contraction typically is sub-critical; and, the flow is supercritical through the barrel of each arch and for a short distance downstream.

Masonry arch bridges readily choke, as Figure 2 indicates for approach flows of increasing value of the shear stress ratio expressed as $\tau_{1} / \tau_{C}=Y_{1} / Y_{c}$. Here, $Y_{1}=$ the normal depth of the approach flow, $\tau_{1}$ is the bed shear stress of the approach flow $\left(=\gamma Y_{1} S\right), \tau_{C}$ is the critical value of bed shear stress associated with the entrainment of a channel's bed material, and $Y_{c}$ is the depth of flow producing $\tau_{c}$ for flow over an alluvial bed of constant slope. This ratio pertains to a channel of constant bed-sediment characteristics and slope. The flowarea ratio, $A_{2} / A_{1}$ has a maximum value set by the cumulative width (at low discharge conditions) of the bridge piers relative to the overall width of the approach flow. As mentioned above, this area ratio reduces when the flow enters the barrel of the arch. The resulting water-surface profile of flow through the arch bridge looks as Figure 3a shows. As a result of choking, supercritical flow occurs through the barrel of the arch and a short distance downstream of the arch, as mentioned above. Figure $3 \mathrm{~b}$ is general for all bridge shapes in a channel of constant bed sediment.

The role of turbulence structures formed at the bridge entrance, the local contraction of flow entering the arch, and the supercritical flow through the bridge play major roles in scour development. With these considerations in mind, a series of flume experiments were conducted to determine the extents to which improving flow into the bridge arch and by armoring the channel bed along the flow approach and through the arch would help mitigate scour. Only a small number of such tests were undertaken.

\section{FLUME EXPERIMENTS}

The flume experiments involved clearwater-scour at single- and double-span arches with variable depth of strip footings. Clearwater scour sufficed for the experiments, which focused on examining the merits of common hydraulic ways to mitigate scour. Of special interest was determining how masonry arch bridges fail owing to scour erosion during choked-flow conditions; i.e., the bridge opening constricts flow, such that the bridge exerts an orifice-flow condition (see Figure 4). Mimicking existing arch bridges, the abutments and piers were founded on relatively shallow footings and sought also to determine how footing depth affects scour depth and progression. The arches were modified by a sequence of adjustments: footing depth, wing walls of variable attack angle were added to the abutments of the single arch; the double-span arch fitted with an optimal angle of wing wall (design practice favours $45^{\circ}$ ); and, modifying the shape of the central-pier cutwater of the doublespan structure. This sequence aimed at establishing how scour leads to failure of such structures, and then identifying how best to minimize scour for the more vulnerable bridges; i.e., those founded on shallow footings. In line with observations of flow conditions commonly associated with scour failure of short-span arch bridges, the experiments simulated conditions of choked flow, whereby the bridge-created backwater caused supercritical flow through the bridge openings. 


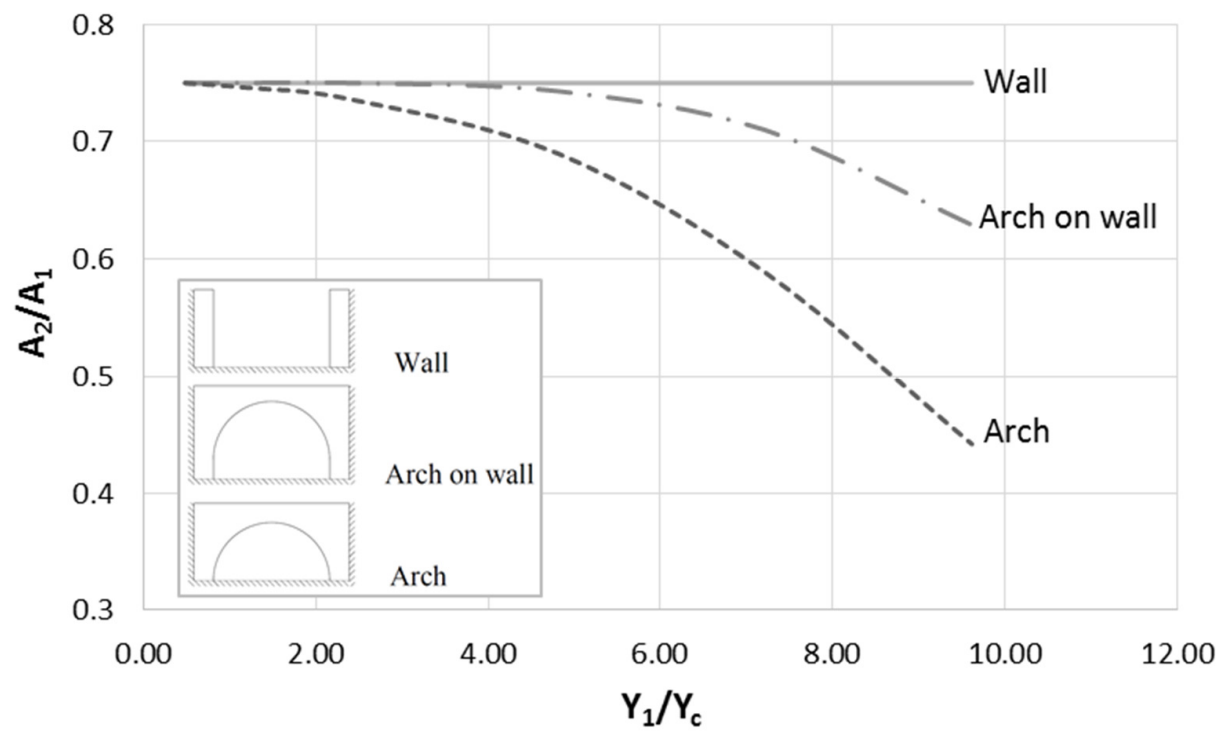

(a)

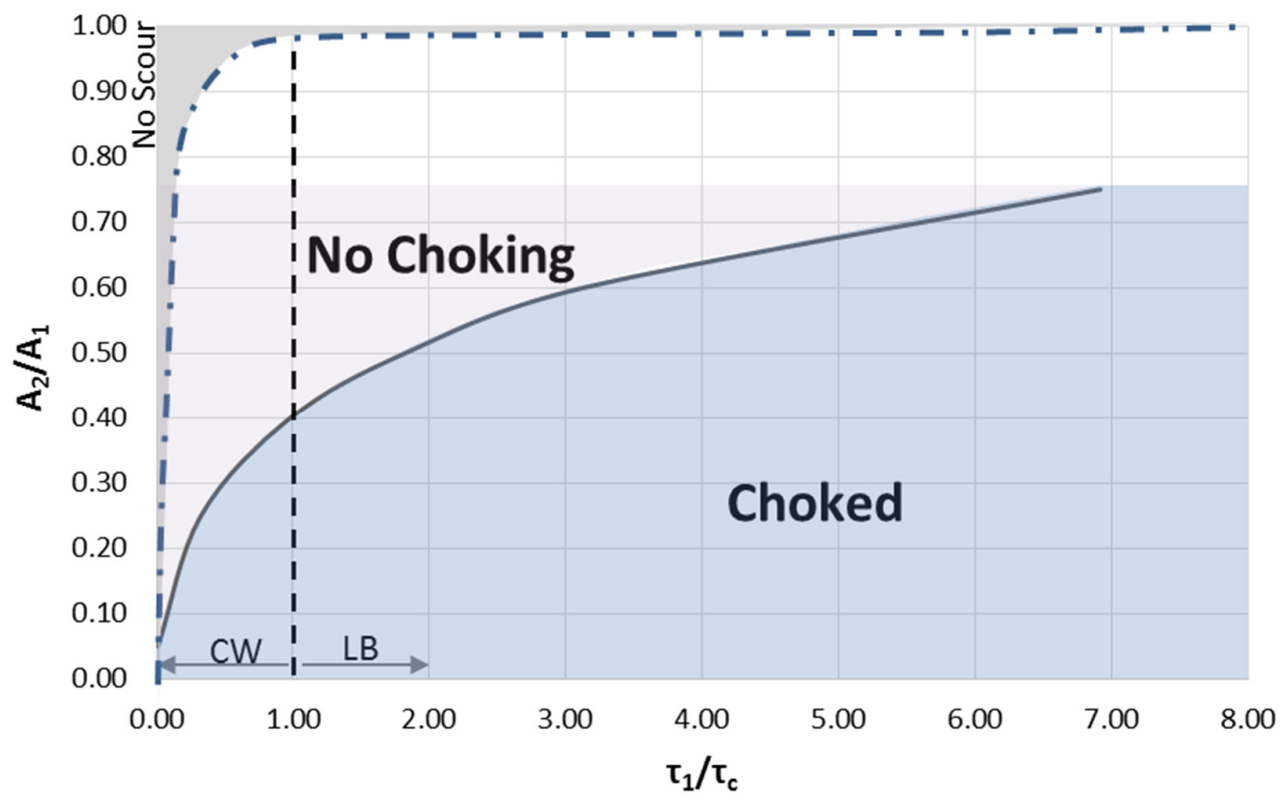

(b)

Figure 2. The condition of choked flow readily occurs at a short-span, masonry arch bridges: (a) shows how the bridge-flow area relative to approach-flow area $\left(A_{2} / A_{1}\right)$ reduces as flow depth increases for arch bridge forms; and, (b) shows the general loci of choking versus non-choking for varying bridge shape but maximum ratio of $A_{2} / A_{1}=0.75$. As $A_{2} / A_{1}$ increases, the loci increase commensurately in extent. (Note: $C W=$ clearwater scour; LB = livebed scour; bed slope $\left(10^{-4}\right)$, channel aspect ratio $\left(B_{1} / Y_{1}=14\right)$, bed sediment and $\tau_{c}$ are assumed constant for these figures.) 


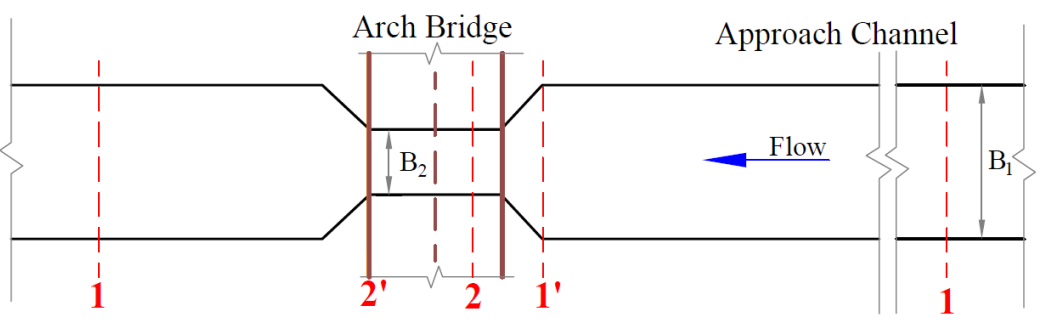

(a)

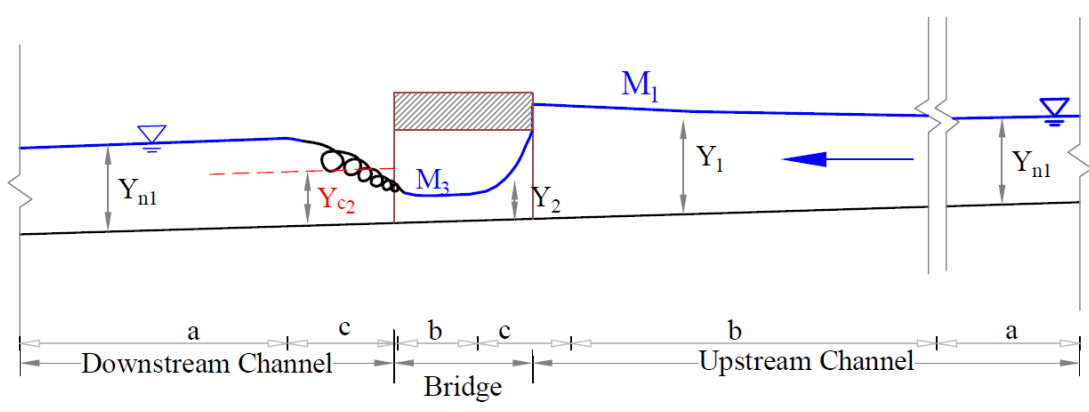

(b)

Figure 3. The water-surface profile associated with choked flow at a short-span masonry arch bridge: (a) plan view of the bridge over a channel; and, (b) water-surface profile of flow through the bridge (The zones denoted "a" are uniform flow, "b" are gradually varied flow and "c" are rapidly varied flow.)

Clear-water approach-flow conditions were used in setting flow through a flow-recirculating flume, $10.0 \mathrm{~m}$ long, $0.75 \mathrm{~m}$ wide and $0.25 \mathrm{~m}$ deep, set at a slope of $\sim 0.1 \%$; the clearwater approach conditions were representative of the failure sites observed, such as shown in Figure 1. A sediment recess $1.8 \mathrm{~m}$-long, $0.75 \mathrm{~m}$ wide by $0.23 \mathrm{~m}$-deep, was placed downstream of the flume's midpoint; and, was filled with uniform, fine gravel. The gravel's median diameter was $D_{50},=2.54 \mathrm{~mm}$ with a coefficient of uniformity, $D_{60} / D_{10}$, of $\sim 3$ and a geometric standard deviation, $\sigma_{g}=\left(D_{84} / D_{50}\right)$ of 1.8 , close enough to negate armouring by coarser grains. This bed sediment was chosen as being representative of the coarse sediments (gravel-bed streams) typical of streams and small rivers in Northern Ireland whose median size $\left(D_{50}\right)$ ranges from about $2 \mathrm{~mm}$ to $256 \mathrm{~mm}$ (Kirby et al. 2015). Thus, the sediment used in the analysis is indicative of the acceptable range of sizes found in UK alluvium stream. The Shield's diagram indicates that the critical shear stress for entrainment of this sediment was about $1.9 \mathrm{~N} / \mathrm{m}^{2}$. The backwater profile of flow ensured that shear stresses on the approach bed to the arches exerted an average bed shear stress less than this magnitude.

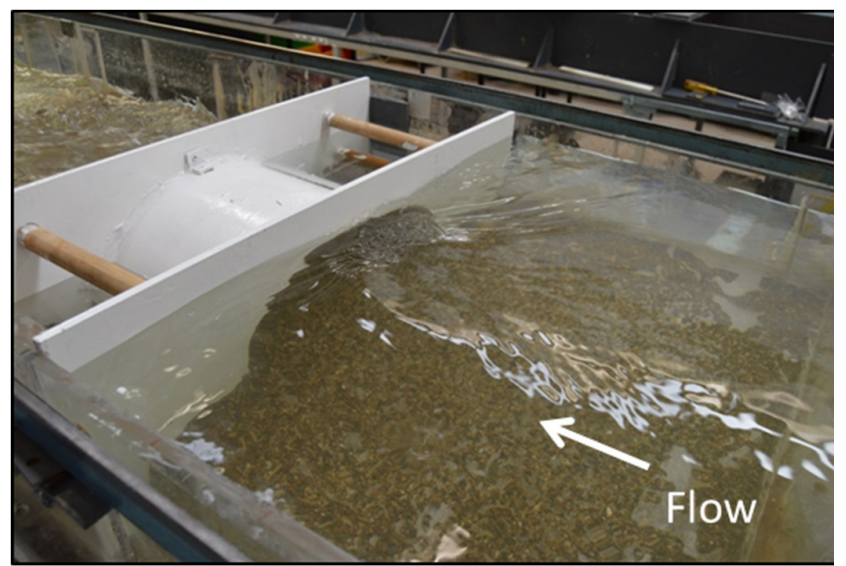

(a)

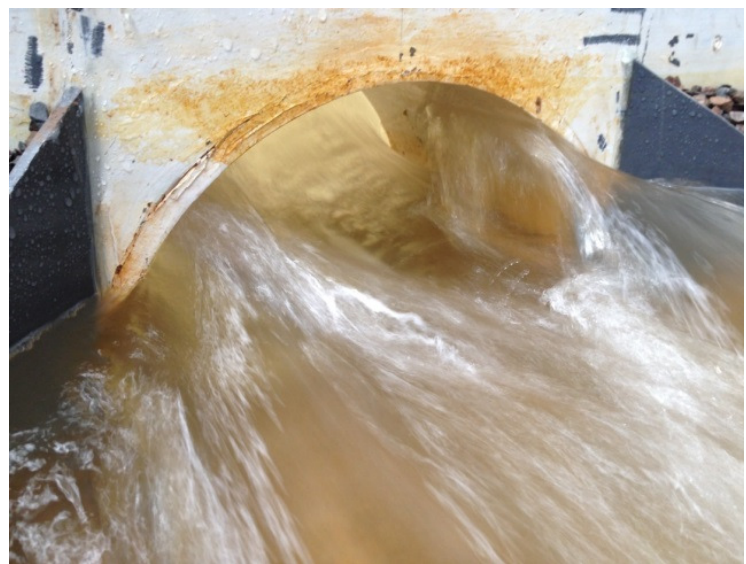

(b)

Figure 4. Two views of contracted flow at the entrance of a simulated, short-span, masonry arch bridge: (a) view from upstream; and, (b) view from downstream. In line with Figures 2 and 3, the choked-flow condition was simulated in the experiments 
Water-surface slopes and associated energy slopes were less that the order of $10^{-4}$; exact values of shear stress ratio, $\tau / \tau_{C}$ were not estimated at the arch, owing to the non-uniform nature of the approach flow. Of primary importance for the experiments was scour variation with footing depth at a test bridge subject to the same range of water flow rates and clear-water approach conditions. Two model spans were selected, a span formed by a single arch and by a double-arch. The single arch had a $0.38 \mathrm{~m}$ internal-diameter, which equates, at 1:25 length-scale to a $9.5 \mathrm{~m}$-wide bridge arch. The streamwise width of the model was $0.3 \mathrm{~m}$, replicating a standard two-lane road $(7.3 \mathrm{~m})$ set between masonry parapets. The spandrel walls adjoining the barrel were made from polypropylene plastic. The wingwalls were made from polypropylene, of similar surface roughness as the arch. Three angles, in addition to no wing wall $\left(0^{\circ}\right)$, were selected for the wing walls: $22.5^{\circ}, 45.0^{\circ}$ and $67.5^{\circ}$. The double arch model comprised two barrels, $0.180 \mathrm{~m}$ in diameter, separated by a $0.11 \mathrm{~m}$-wide pier. The upper and lower spandrel walls of the arch were formed from painted, marine plywood. Three magnitudes of water discharge were used $\left(0.03,0.04\right.$ and $\left.0.05 \mathrm{~m}^{3} / \mathrm{sec}\right)$, each of which represented various storm intensities. In each case the upstream end of the approach flow depth was controlled at about $\sim 0.2 \mathrm{~m}$, for all flow rates, using a tailgate, and a backwater effect caused by flow choking at the arch models resulted in the water level rising above the crown of each arch barrel. The water level at the crown varied with discharge and was a maximum of about $0.025 \mathrm{~m}$ for the largest flow used and reduced to about $0.01 \mathrm{~m}$ for the lowest flow. Approximate values of shear stress on the approach bed, $\tau_{o}$, were estimated, in terms of Manning's $n$ and friction slope of approach flow and related to the critical value of bed shear stress, $\tau_{c}$, for entrainment of the bed sediment in the sediment recess; $\tau_{c}$ was estimated using the Shields entrainment criterion (e.g., ASCE 2008). Values of the shear stress ratio, $\tau / \tau_{c}$ were estimated to remain in the clear-water range. Additionally, values of Reynolds number for flow through to the entrance of the arch were in excess of $10^{5}$, thus ensuring fully turbulent flow. Velocity measurements were taken using an Acoustic Doppler Velocimeter (ADV) with a sampling frequency of $50 \mathrm{~Hz}$. Once the velocities were measured, the scour testing ran until an equilibrium erosion stage (approx. 120 mins) was reached. The scour measurements were made through water using an electronic point gauge (Sylvac Digital Scale) attached to a mobile mount. When the test was completed the arch was carefully removed, leaving the foundations in place, and scour depth measurements were taken along the centreline of the channel and in detail at the abutment corners where scour depth was greatest.

\section{HYDRAULIC MEANS FOR SCOUR MITIGATION}

The experiments investigated hydraulic means (flow streamlining and bed armouring) to mitigate scour. The intended role of flanking wingwalls was to streamline flow approach to the barrel of an arch, thereby reducing scour depth at the arch. Figure 5 presents the data from the flume experiments. The data show clear trends that, at the lower flow rates, the maximum depth of scour reduced as wingwall angle of the single arch increased from $0^{\circ}$ to $67.5^{\circ}$. This reduction in scour depth is largely attributable to the reduction in the magnitude and vorticity of the turbulence structures developed at the upstream corners of the arch. For wingwalls set at $22.5^{\circ}$ and $45^{\circ}$, the scour-reduction effect was modest, with practically no effect for the two highest discharges tested. For the wingwall setting of $67.5^{\circ}$, wingwall mitigation of scour diminished from about $36 \%$ to $10 \%$ over the discharge range. The increased ineffectiveness of wingwalls at the higher discharges (Figure 6), for which choking increased, is due to the increased submergence of the arch crown and therefore more flow entering the arch barrel from a flow region above the wingwalls. The trends in Figures 5 and 6 concur with findings reported by Kerenyi et al., (2003), who show that entrance conditions influence scour depth at bottomless culverts for flows when the culvert crown was unsubmerged; i.e., un-choked. For un-choked approach-flow condition, Kerenyi et al., (2003) indicates, that a wingwall presence reduces scour depth to about 87 to $91 \%$ of the no wing walls condition.

Observations showed that a pier cutwater streamlined the flow around a pier linking two arches, and thereby reduced the strength of turbulence structures formed at the pier. Figure 6 indicates for a pier, that the use of the large cutwater reduced scour depth at the pier exposed to the two smaller flow rates. The maximum reduction in scour depth was about $45 \%$ for the big cutwater when the flow rate was $0.03 \mathrm{~m}^{3} / \mathrm{s}$. The small cutwater had essentially no effect in reducing scour depth. This lack of impact is attributed to the inability of the small cutwater to alter the intake and emerging submerged jet on the respective faces of the bridge. As water discharge increased, the effect of the large cutwater diminished. The influence of pier streamlining diminished over the range of discharges tested because the greater choking of approach flow at the higher discharges (especially at $0.05 \mathrm{~m}^{3} / \mathrm{s}$ ) further raised the water elevation at the arch entrance. For the highest discharge, $0.05 \mathrm{~m}^{3} / \mathrm{s}$, the large cutwater reduced scour depth by only $3 \%$. Armour stone is sometimes placed to protect the bed through the barrel of an arch in the U.K., as stone is deemed an environmentally more friendly solution than concrete aprons. The stone-sizing relationship recommended by Lagasse et al., (2006) was used to estimate a suitable armour size, with the stone then scaled to conform to the present experimental study. Though only a small number of tests were conducted, it showed that the stone inhibited scour at the entrance corners of the double arch and inhibited scour along the barrel of each arch under low flow conditions $\left(0.03 \mathrm{~m}^{3} / \mathrm{sec}\right)$. This finding shows that stone armouring substantially reduces scour at the entrance and within bottomless culverts. However, the present experiment also showed that flow issuing from the arches scoured a depression in the bed downstream of the double arch, as Figure 7 illustrates for the flume experiments. Recent field experience, 
involving the failure of armour stone downstream of a masonry arch bridge (Figure 8) corroborates this finding, and shows that stone immediately downstream of the bridge had to be sufficiently large to withstand the highexit velocity flow for unsubmerged and submerged flow conditions.

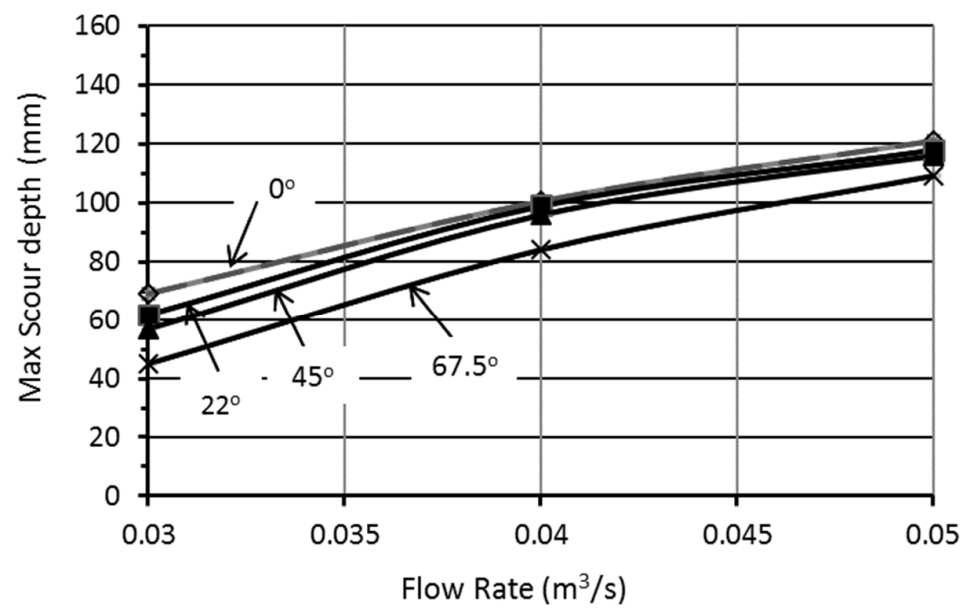

Figure 5. Maximum scour depth for a single arch with $45 \mathrm{~mm}$ deep foundations and variable angle of wingwall

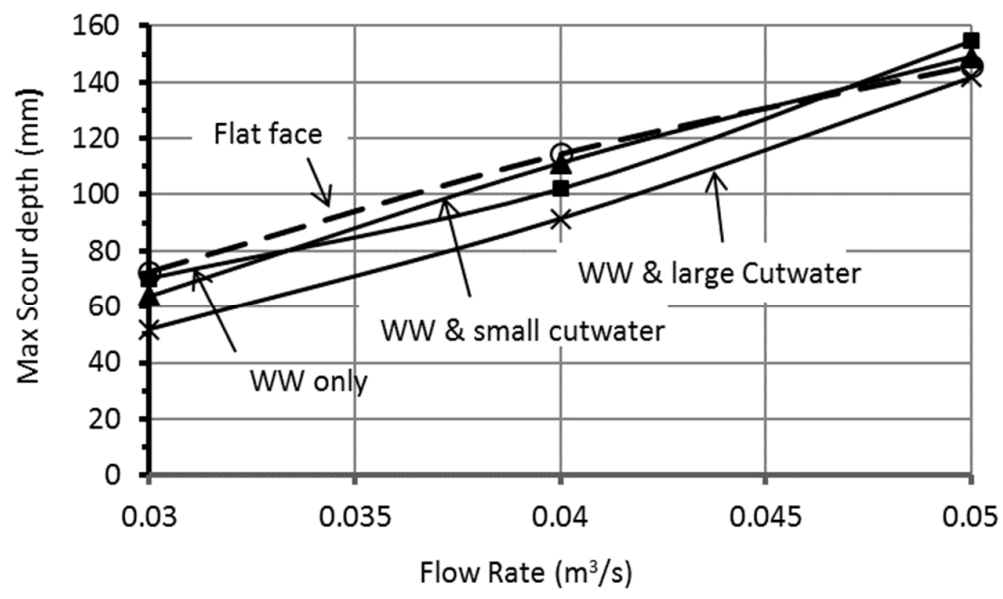

Figure 6. Variation of maximum scour depth at centre pier versus flow rate (75mm-deep footings)

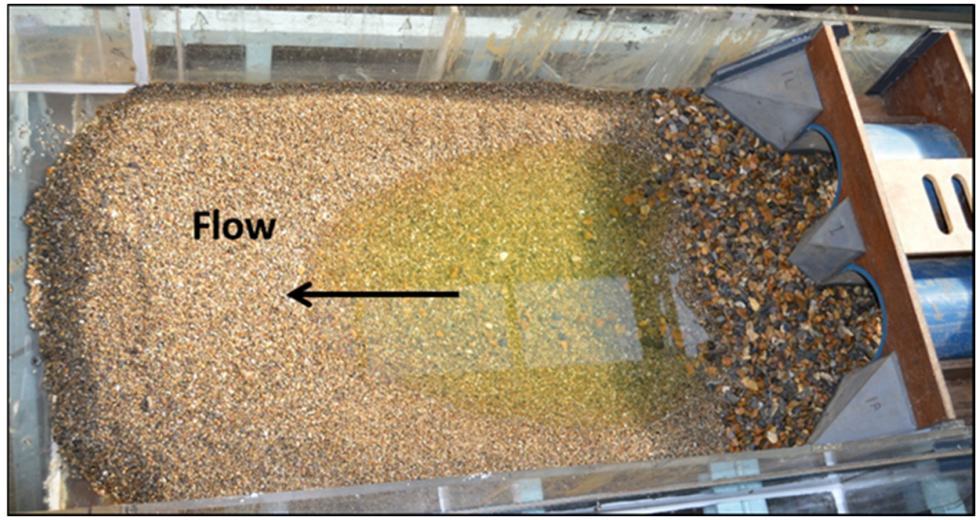

Figure 7. Armoured twin-span arch with scour developing upstream (toward bridge) with time 


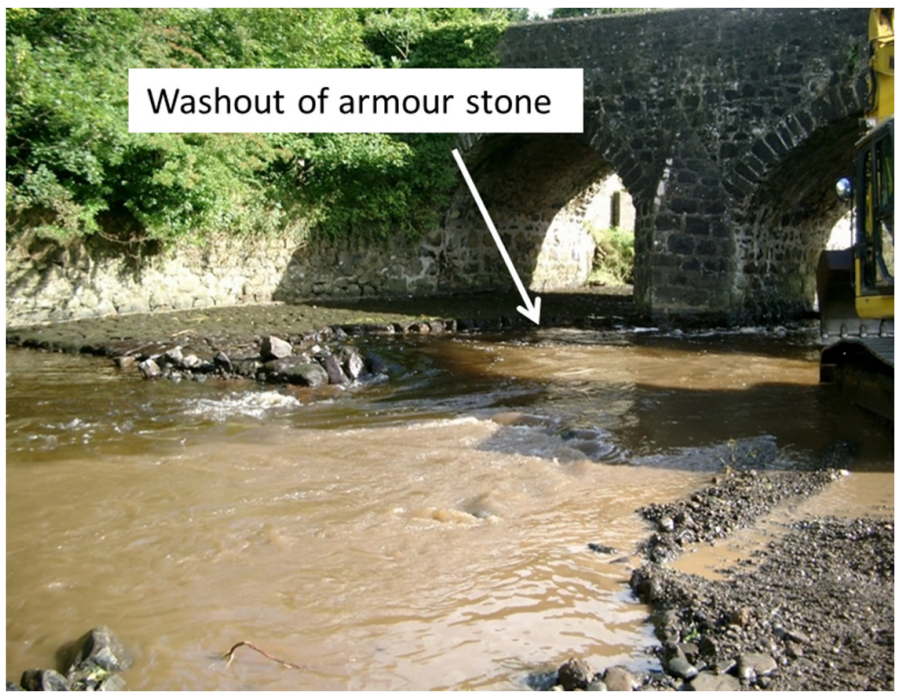

Figure 8. Supercritical flow immediately downstream of this arch bridge washed out armour stone placed there, and then (via a head-cutting mode) eroded the downstream bed; Co. Antrim, Northern Ireland

\section{CONCLUSIONS}

Masonry arch bridges on shallow footings are highly vulnerable to scour, a concern aggravated by the common occurrence of approach-flow choking, a common feature of flow through such bridges. This paper presents the findings from a review of scour concerns and an extensive series of flume experiments. The findings showed that the deepest scour developed at the leading corners of arch abutments or at piers in a multi-span arch bridge. Scour depth increased with water discharge in a similar manner as local scour at a bridge pier. Additionally, the shallower footing tested caused scour to develop more quickly, because more flow could pass under the footing than for the deeper footing and attain an equilibrium condition.

Hydraulic measures, notably wingwalls and cutwaters, have only a moderate effect in reducing maximum depth of scour because of the common flow feature of approach-flow choking. At the lower flow rates tested, scour depth at the abutment corner of an arch can be reduced by approximately $20 \%$ by using wingwalls set at $45^{\circ}$, a commonly used angle. Wingwall effects reduced as flow rate increased, because increased inlet submergence of an arch reduced the effectiveness of wingwall presence. Scour depth at a pier between adjoining arches can be reduced approximately $33 \%$ by means of an enlarged cutwater, compared with scour at a flat-faced pier. Current prediction methods have not addressed yet the two-dimensional constriction of flow associated with arch structures, and thus give scour depths and locations that are not consistent with the scour patterns observed during the present flume tests. This is an area in need of further research. In combination with the mitigation actions mentioned above, placement of armor stone at the entrance and through the barrel of an arch can eliminate scour at the upstream corners and through the barrel. However, flow passing through the barrel may then scour the channel bed downstream of the bridge, similar to scour downstream of a culvert. This form of scour may evolve as head-cutting and progress upstream undermining the bridge from its downstream side. For suitable sites, flow bypassing may ease flow choking by means of the use of adjacent culverts sized to bypass some flow around the bridge.

\section{ACKNOWLEDGMENTS}

This study was conducted with funding from U.K. Royal Society, under Award No. IE140568. Thanks are due to Dfl Senior Engineer, Mr. John McRobert (now retired), for encouraging and guiding this study, and to Mr. Mark Wilson, the hydraulics technician at Ulster University.

\section{REFERENCES}

ASCE (2008). Sedimentation Engineering. ASCE Manual of Practice 110, American Society of Civil Engineers, Reston, VA.

Arneson, L.A., Zevenbergen, L.W., Lagasse, P.F. and Clopper, P.E. (2012), Submerged Flow Bridge Scour under Clear Water Conditions. Report No. FHWA-HRT-12-034, Federal Highways Administration, Washington, D.C.

Baecke, E. (2015). "Reconstruction of Blackfriars Railway Bridge." Bridge Engineering, Proc. of the Institution of Civil Engineers, London, U.K., 1-12.

BBC (2015) Storm Desmond: Your questions answered. Available at: https://www.bbc.co.uk/news/uk-35038617 (Accessed: 09.05.19). 
Benn, J. (2012). "Railway bridge failures during flooding in the U.K. and Ireland." Forensic Engineering. Proc. of the Institution of Civil Engineers, (166), 163-170.

Brencich, A. and Morbiducci R. (2007). "Masonry arches: historical rules and modern mechanics." International Journal or Architectural Heritage, (1), Taylor and Francis, London, U.K., 165 -189.

Citto, C. and Woodham, D.B. (2015). Evaluating existing and historic stone arch bridges." Structural Forensics, Structure Magazine, May, Washington, D.C.

Dfi (2015) McRoberts, J. Personal communication, Department for Infrastructure, Northern Ireland.

Dfl (2018), Northwest flooding review. Department for Infrastructure, London, U.K.

Ebrahimi, M., Kripakaran, P., Djordjevic, S., Tabor, G., Kahraman, R., Prodanović, D.M. and Arthur, S. (2016). Hydrodynamic effects of debris blockage and scour on masonry bridges: towards experimental modeling. Scour and Erosion, Ed. by Harris, J., Whitehouse, Moxon, S.R., CRC Press, London, U.K., 743-750.

EU (2007). The EU Floods Directive: OJL: European commission. (online accessed 05/05/2018).

Hamill, L. (1993). "A guide to the hydraulic analysis of single-span arch bridges," Municipal Engineer, Proc. of the Institution of Civil Engineers, U.K., (98), 1-11.

Hamill, L. (1999). Bridge Hydraulics. E \& FN Spon, London, U.K.

Kerenyi, K.J., Jones, S. and Stein, S. (2003). Bottomless culvert scour study: Phase I Laboratory Report. Report No. FHWA-RD-02-078, Federal Highways Administration, Washington, D.C.

Kerenyi K.J., Jones, S. and Stein, S. (2007). Bottomless culvert scour study: Phase II Laboratory Report. Report No. FHWA-HRT-07-026, Federal Highways Administration, Washington, D.C.

Kindij, A, Ivankovic, M.A. and Vasilj, M. (2014). "Adjustment of small-span masonry arch bridge to present-day demands", Gradevinar, (66), 37-49.

Kirby, A.M., Roca, M., Kitchen, A., Escarameia, M. and Chesterton, O.J. (2015). Manual on scour at bridges and other hydraulic structures. Construction Industry Research and Information Assoc., Report C742, London, U.K.

Lagasse, P., Clopper, P.E., Zevenbergen, L. and Ruff, J.F. (2006). Riprap design criteria, recommended specifications and quality control. NCHRP Report 568, Transportation Research Board, Washington, D.C.

Lagasse, P., Clopper, P.E., Zevenbergen, L., Spitz, W. and Girard, L. (2010). Effects of debris on bridge pier scour. NCHRP Report 653, Transportation Research Board, Washington, D.C.

Maddison, B. (2012). "Scour failure of bridges". Proceedings of the Institution of Civil Engineers - Forensic Engineering, 165(1), pp. 39-52. doi: 10.1680/feng.2012.165.1.39.

McIntyre, F. (2018) "Tech Excellence Brougham Old Bridge Repairs" The New Civil Engineer (online accessed 05/05/2018)

McKibbins, L.D., Melbourne, C., Sawar, N. and Gaillard, C.S. (2006). Masonry arch bridges: condition appraisal, and remediation treatment." CIRIA, London, U.K.

Novak, P. Moffat, A.B., Nalluri, C. and Narayanan, R. (2007), Hydraulic structures. Fourth Ed., Taylor \& Francis, London, UK.

O'Keefe, P. and Simington, T. (2016). Stone bridges - history and heritage of masonry arch bridges in Ireland. Irish Academic Press, Newbridge, Ireland.

Owen, H.J., Sooky, A., Husain. S.T. and Delleur, J.W. (1959). "Hydraulics of river flow under arch bridges." Progress Report, Joint Highway Project C-36-62B, Purdue University, IN.

Ryan, D., Ettema, R., Solan, B. and Hamill, G. (2016). "Arch bridges under flood conditions, a study of velocity distributions, and the resulting bed scour." Proc. Civil Engineering Research in Ireland, Civil Engineering Research Association of Ireland, Galway, Ireland.

Ryan, D., Ettema, R., Solan, B. and Hamill, G. (2015). 'Stability of short span bridges to overtopping during flooding: case studies from Ireland and the USA. In e-Proc. of the 36th IAHR World Congress 28 June 3 July 2015, The Hague, The Netherlands, 1-11.

Salter, G (2013). "Spanning the Centuries - The Masonry Arch". Presentation to Engineers Ireland (13 ${ }^{\text {th }}$ Nov) Dublin, Ireland.

Sassu, M., Giresini, L. and Pupio. M.L. (2017). "Failure scenarios of small bridges in extreme rainstorms." Proc. Sustainable and Resilient Infrastructure, Taylor and Francis, London, U.K.

Shan, H., Xie, Z., Bowanowski, O., Suaznabar, O., Lottes, S., Shen, J. and Kerenyi, K. (2012). Submerged Flow Bridge Scour Under Clear Water Conditions. Report No. FHWA-HIF-003-HEC18, Federal Highways Administration, Washington, D.C.

U.K. Government (2010). The impact of flooding on bridges and other infrastructure in Cumbria. Government Publications, London, U.K.

U.K. Government (2011). Climate resilient infrastructure: preparing for climate change. London. Government Publications, London, U.K.

Van Leeuwen, Z. and Lamb, R. (2014). "Flood and scour related incidents at railways assets between 1846 and 2013." JPA Trust Limited, North Yorkshire, U.K.

Wilmers, W. (2012). "Restoration of masonry arch bridges." Bridge Engineering (165 BE), Proc. of the Institution of Civil Engineers, U.K., 135-146.

Wiggins, D., Mudd, K., and Healey M (2018), "Rehabilitation of Brougham Castle Bridge, UK", Proceeding of the Institution of Civil Engineers - Engineering History and Heritage, https://www.icevirtuallibrary.com/doi/abs/10.1680/jenhh.18.00027 
E-proceedings of the 38th IAHR World Congress

September 1-6, 2019, Panama City, Panama

Zampieri, P., Zanini, M.A., Faleschini, F. and Hofer, L. (2017). "Failure analysis of masonry arch bridges subject to local pier scour." Engineering Failure Analysis, (79), 371-384. 